\title{
Educational activities with the elderly in vulnerable situations
}

\author{
Ação educativa com idosos em situação de vulnerabilidade \\ Acción educativa con ancianos en situación de vulnerabilidad
}

Deyla Moura Ramos Isoldi ${ }^{1}$, Ana Michele de Farias Cabral ${ }^{1}$, Clélia Albino Simpson ${ }^{1}$

This study aimed at analyzing the knowledge of the elderly on the prevention of AIDS before and after the practice of education in health. This is a quasi-experimental study with a quantitative approach, performed in the Social Assistance Reference Centers, with 60 seniors. It was developed in Parnamirim, RN, Brazil, from February to June 2014. Data were collected through a questionnaire with closed questions about AIDS. In principle, most patients (61.6\%) said they did not know what AIDS was, but this soon became reality after conducting a dialog lecture as a health education tool. There was a statistically significant difference. We conclude that education about AIDS is important to adopt a collective vision on the various socio-cultural contexts in which the elderly are inserted.

Descriptors: Aged; Acquired Immunodeficiency Syndrome; Health Education; Health Promotion; Nursing.

Objetivou-se analisar o conhecimento de idosos sobre a prevenção da aids antes a após a prática da educação em saúde. Trata-se de um estudo quase experimental, com abordagem quantitativa, realizado nos Centros de Referência de Assistência Social, com 60 idosos. Desenvolveu-se em Parnamirim, RN, Brasil, de fevereiro a junho de 2014. Para coleta de dados aplicou-se um questionário contendo questões fechadas sobre aids. Em princípio, a maioria dos idosos (61,6\%) afirmaram não saber o que é a aids mas, esta realidade logo se transformou após a realização de uma aula expositiva dialogada como instrumento de educação em saúde. Houve diferença estatisticamente significativa. Conclui-se que as ações educativas sobre a aids são importantes para adoção de uma visão coletiva sobre os variados contextos socioculturais em que os idosos estão inseridos. Descritores: Idoso; Síndrome da Imunodeficiência Adquirida; Educação em Saúde; Promoção da Saúde; Enfermagem.

El objetivo fue analizar el conocimiento de ancianos acerca de la prevención del SIDA antes y después de la práctica de educación para salud. Estudio cuasi-experimental, con enfoque cuantitativo, realizado en los Centros de Referencia de Asistencia Social, con 60 ancianos. Fue desarrollado en Parnamirim, RN, Brasil, de febrero a junio de 2014. Los datos fueron recolectados a través de aplicación de cuestionario con preguntas cerradas sobre SIDA. En principio, la mayoría de los ancianos $(61,6 \%)$ declararon que no sabían lo que era el SIDA, pero la realidad se convirtió después de la realización de una conferencia basada en el diálogo como herramienta de educación para salud. Hubo diferencia estadísticamente significativa. En conclusión, acciones educativas sobre SIDA son importantes para adoptar visión colectiva acerca de los diversos contextos socio-culturales en que los ancianos están inseridos.

Descriptores: Anciano; Síndrome de Inmunodeficiencia Adquirida; Educación en Salud; Promoción de la Salud; Enfermería.

\footnotetext{
${ }^{1}$ Universidade Federal do Rio Grande do Norte. Natal, RN, Brazil.

Corresponding author: Deyla Moura Ramos Isoldi

Rua Girassol, 250 - Jardim Planalto. CEP: 59155-310. Parnamirim, RN, Brazil. E-mail: deylinha@hotmail.com
} 


\section{Introduction}

The high rate of elderly contaminated by Acquired Immunodeficiency Syndrome (AIDS) is due to the view of invisibility of the population concerning the idea of seeing themselves sexually active. However, the aging of the population and the new technologies which prolong sexual life, this sexuality until then ignored, emerges as a matter to be discussed ${ }^{(1)}$.

Aging is regarding as a set of effects which occurs throughout the years. Biologically, it corresponds to an involution which affects all the physiological systems of the body, but which does not necessarily interfere in his welfare; psychically, it is a phase which demonstrate maturity, knowledge and comprehension of life, arising from the experiences lived through by the subjects ${ }^{(2)}$.

However, even with the guarantees provided by Law 10.741/2003, which stablishes the Senior Citizens' Statute; the prejudices and the denial of the society concerning old age still exist, hindering the elaboration of public policies directed and put into practice based on adequate, individualized and holistic attention. This question is strengthened when the national statistics referring to the incidence of AIDS are observed in this population. Data provided by the Health Department reported a figure of 32,167 cases of AIDS in people older than 50 years of age in Brazil, and of those, 9,918 patients are 60 years old or older ${ }^{(2)}$.

The increase of the incidence of AIDS among the elderly is highlighted as a worldwide trend and shows the importance of studies which analyze the situation of the epidemics in this population, once they can subsidize the directing of action in health ${ }^{(3)}$. Prevention of such disease is the main goal of education in health, requiring and anticipating action to reduce the incidence and prevalence of the same in the population $^{(4)}$.

Education in health is able to act on the knowledge of the people in order to provide development of criticality and capacity of intervention on their own lives ${ }^{(5)}$.
Besides that, the educative actions are characterized by transforming habits of life of a population making them able to be responsible for their health ${ }^{(6)}$. In this study, education in health highlights the elderly, once they are the center of the educational process, enabling the contribution for the prevention of AIDS in the group.

For this reason, it is necessary to develop and educative approach for the elderly, so that this people can become more well informed on the AIDS and know how to protect themselves, once education and information on health enables the promotion of knowledge.

Facing the reality which permeates AIDS, the importance of the education in health in the prevention of that disease is noticed. However, the justification for the present study consists in the need of practices to be used to favor the divulgation of information concerning AIDS, once such disease is seen as public health problem in Brazil.

Under such perspective, the following question arises: up to which extent do the elderly understand what AIDS involves? Therefore, the present research had the objective to analyze the knowledge of the elderly on the prevention of AIDS, before and after the practice of education in health.

\section{Method}

It is a quasi-experimental study, with quantitative approach, made in the Centros de Referência de Assistência Social (Centers of References of Social Assistance) in the county Parnamirim, RN, Brazil, from February to June 2014 with elderly enrolled in the Serviços de Convivência and Fortalecimento de Vínculos (Services of Experiences and Strengthening of Links).

Among the action of the Unified System of Social Assistance, there is the Services of Experiences and Strengthening of Links for the elderly, whose objective is to contribute to a process of active healthy and autonomous aging, to assure venues of meetings for 
the elderly and intergenerational meetings in order to promote the family and communitarian experiences; to detect needs and motivations and to develop potentialities and capacities for new projects of life, to provide ways of living which value the experiences and stimulate and maximize the condition of choosing and deciding. This will contribute for the development of the social autonomy of the users ${ }^{(7)}$.

The meetings at the venue of the study happen weekly, aiming at strengthening the social links of the elderly with activities of sport and leisure, culture, craft workshops, information lectures, nutritional, social and elderly health assistance, respecting the conditions of accessibility, physical and mental fitness and the integration through a multidisciplinary team formed by Educators, Social workers, Psychologists and Artisans.

The population of the study was made up by 132 elderly registered in the groups of experience of four neighborhoods of the county. The sample consisted of 60 elderly in situation of social vulnerability. It is highlighted that the total number of subjects which formed the sample was selected from criteria of inclusion and exclusion of the present study.

The following 60 elderly people who presented these criteria of inclusion participated in the research: elderly who were present at the meeting on the day of the lecture and the filling of the questionnaire who demonstrated interest in participating in the research.

As criteria of exclusion the following issues were considered: not be registered at the Centers of References of Social Assistance, being absent during the research, as well as the ones who did not allow their participation.

Regarding the illiterate or semi-literate elderly, students of graduation in nursing of the $4^{\text {th }}$ period, helped with the reading of the questionnaire.

The instrument used in the data collection was a questionnaire with 7 closed questions on AIDS, based on the Cadernos de Atenção Básica (Notebooks of Basic Attention) no. 18 and no. 19, published in 2006 by the Health Department.
Aiming at the assistance of the objective proposed of the study, the data collection occurred in 3 distinct phases: in the first phase, the pre-test, was applied using a questionnaire with closed questions; in the second phase there was a dialog expositive class such as activities of education in health, considering the previous knowledge of the elderly concerning AIDS, in order to clarify their doubts on the diseases; later on, in the third phase, the post-test, the questionnaire was reused.

The data obtained in the questionnaire were recorded, organized and categorized in e-spread sheet of Microsoft Office Excel for quantitative analysis and absolute and percentage values were expressed. For the statistical analysis the chi-square was used, considering the level of significance of $5 \%(\mathrm{p}<0.05)$.

The research was submitted and approved by the Committee of Ethics of the Universidade Federal do Rio Grande do Norte, Brazil, under no. 30408114.5.0000.5537, with legal opinion no. 719.926 and complied with Resolution 466/12 of the National Health Council, in force, for researches involving human beings.

\section{Results}

It was noticed that in the phase of pre-test, only $38.3 \%$ of the elderly knew what AIDS was and concerning the etiology of the disease less than half answered correctly, when reporting that the causing agent was a virus.

In the matter concerning vaccination against AIDS, still in the period of pre-test, 28 elderly answered inadequately and stated there was such vaccine. Concerning the possible manner to acquire HIV, $83.3 \%$ stated to make sex without protection. When questioned if HIV bearers could donate blood, 53 elderly answered correctly reporting that it was not possible, once it is possible acquire the virus through blood donation. Concerning the cure of AIDS most of them answered that there was no cure.

After the activity of education on health, the re- 
sults reflect the significant change of the learning the elderly obtained facing the thematic. And such change is materialized in the values presented in the post-test.

It should be highlighted that of all the elderly, 85\% knew what AIDS was, 48 elderly answered correctly on the etiology of the disease, stating to be a virus and concerning the vaccination against AIDS, $86.7 \%$ answered it did not exist. It was noticed that there was statistically significant difference between the pre-test and the post-test concerning the knowledge of AIDS, the cause of the disease and the existence of the vaccine, where the elderly after the post-test presented a higher percentage of knowledge concerning those issues.

With all the elderly (60) receiving information about AIDS, 55 stated that it is possible to acquire the virus making sex without protection, not being statistically significant ( $\mathrm{p}=0.256)$ and $93.3 \%$ stated that the people with HIV could not donate blood.

According to the question 'does AIDS have cure?', fifty seven elderly (95\%) answered correctly reporting that there is no cure and it was noticed that there was statistically significant difference between the pre-test and the post-test concerning this issue $(\mathrm{p}=0.000)$.

\section{Discussion}

The study revealed that the educational level directly interferes in the development of the vulnerability and infection due to HIV, and there was a considerable relevance when educative campaigns are developed adequately, once the less access to information there is, the more vulnerable AIDS will be. Studies show that people with higher schooling tend to better assimilate information ${ }^{(3-8)}$.

It is observed that the matters related to AIDS and sexuality have stronger emphasis for the specific population such as adolescents, and they are insufficient on the aspects of the promotion of sexual health and the prevention of Sexually Transmissible
Table 1 - Knowledge of the elderly on AIDS, in the pre-test and in the post-test

\begin{tabular}{|c|c|c|c|}
\hline Adequate/Inadequate Knowledge & $\begin{array}{l}\text { Pre-test } \\
\text { n(\%) }\end{array}$ & $\begin{array}{l}\text { Post-test } \\
\text { n(\%) }\end{array}$ & $\begin{array}{c}\mathbf{P} \\
\text { Value }\end{array}$ \\
\hline \multicolumn{4}{|l|}{ What is AIDS? } \\
\hline Yes & $23(38.3)$ & $51(85.0)$ & \multirow[t]{2}{*}{$0.000^{*}$} \\
\hline No & $37(61.7)$ & $9(15.0)$ & \\
\hline \multicolumn{4}{|l|}{ Etiology (cause) of AIDS } \\
\hline Bacterium & $5(8.3)$ & $6(10.0)$ & \multirow[t]{3}{*}{$0.000 *$} \\
\hline Virus & $28(46.7)$ & $48(80.0)$ & \\
\hline I do not know & $27(45.0)$ & $6(10.0)$ & \\
\hline \multicolumn{4}{|l|}{ Vaccine against AIDS? } \\
\hline Yes & $28(46.7)$ & $8(13.3)$ & \multirow[t]{2}{*}{$0.000^{*}$} \\
\hline No & $32(53.3)$ & $52(86.7)$ & \\
\hline \multicolumn{4}{|l|}{ Possibility to acquire HIV } \\
\hline Hugging/Hand shaking & - & $1(1.7)$ & \multirow[t]{3}{*}{0.256} \\
\hline Sex without protection & $50(83.3)$ & $55(91.6)$ & \\
\hline Drinking water in the same glass & $10(16.7)$ & $4(6.6)$ & \\
\hline \multicolumn{4}{|l|}{ Can people with HIV donate blood? } \\
\hline $\begin{array}{l}\text { Yes. it is not transmissible through } \\
\text { blood transfusion }\end{array}$ & $3(5.0)$ & $1(1.7)$ & \\
\hline Yes. up to 6 months after infection & $4(6.6)$ & $3(5.0)$ & \multirow[t]{2}{*}{0.838} \\
\hline $\begin{array}{l}\text { No. it is possible to acquire HIV } \\
\text { through blood donation }\end{array}$ & $53(88.4)$ & $56(93.3)$ & \\
\hline \multicolumn{4}{|l|}{ Does AIDS have cure? } \\
\hline Yes & $18(30.0)$ & $3(5.0)$ & \multirow[t]{2}{*}{$0.000^{*}$} \\
\hline No & $42(70.0)$ & $57(95.0)$ & \\
\hline \multicolumn{4}{|l|}{ Would you take the anti-HIV test? } \\
\hline By curiosity & $29(48.3)$ & $30(50.0)$ & \multirow{3}{*}{0.999} \\
\hline $\begin{array}{l}\text { By concern with the experienced } \\
\text { situation }\end{array}$ & $21(35.0)$ & $21(35.0)$ & \\
\hline I would not take the test & $10(16.7)$ & $9(15.0)$ & \\
\hline
\end{tabular}

Diseases, such as AIDS for the elderly ${ }^{(9)}$. A great part of the population tends to deny the sexuality of the elderly especially due to the prejudice related to the sexual acts at this age ${ }^{(8)}$. Because of that, it is believed that the elderly end up showing little interest in the search of knowledge of the thematic.

The elderly population has been conquering their freedom in the sense of expressing and exercising their sexual activity due to the improvement of the quality of life ${ }^{(10)}$ and new technologies ${ }^{(11)}$. Such concern is due to the fact that this elderly were not dully guided on the use of pre-conceptives ${ }^{(11)}$, as reported by the elderly during the development of the research. 
The importance of preventive actions is highlighted, as well as the capacitation of the nursing professionals, enabling that a higher number of elderly are guided. The lack of preparation of the health/nursing professionals becomes a barrier for the education for the elderly on the risks of the disease ${ }^{(12)}$.

A study made in Spain shows that the risk caused by the infection due to HIV represents an important indicative to health care, and the immigrants are a diversified group and more susceptible due to the small amount of information they receive on HIV, indicating more social vulnerability of the immigrants due to a deep inequality among the groups ${ }^{(13)}$.

In researches in Southern Africa, it was evident that the elderly have knowledge of the transmission of HIV from one person to another person, although some did not believe in the infection for sharing utensils. However, the use of contraceptives is a challenge to be overcome due to the refusal of the husbands to use them, which significantly contributes for the elderly women to be under the risk of HIV infection. This phenomenon is associated to inequalities of gender which place the women in a subordinated position, transforming it in a central obstacle for the prevention of AIDS in Africa ${ }^{(14)}$.

Due to the biopsychosocial context in which the elderly is inserted, it is noticed that old age corresponds to a phase of vulnerability to infection by HIV in different countries.

The concept of vulnerability is highlighted, once AIDS can reach the whole society not choosing sex, color or age range ${ }^{(15)}$. Thus, it its highlighted that the social vulnerability to HIV/AIDS, can be explained by three factors which are interrelated: the individual one, related to behavior which makes acquiring the diseases easily; the social one, turned to the access of information and sociopolitical aspects; and programmatic ones, related to the commitment of the authori$\operatorname{ties}^{(16-17)}$.

The elderly become many times vulnerable, once part of the society and the health professionals do not know the sexual practice of the elderly ${ }^{(1)}$.

So, the health professionals, especially the nur- ses, need to widen their knowledge concerning the elderly, valuing their context of life and directing the orientations, so that the social-cultural factors do not interfere in the prevention, assisting them completely ${ }^{(18)}$. The complete approach provides tools for a better understanding of the context of the disease.

\section{Conclusion}

With this study, it was observed that the elderly do not receive information on the prevention of AIDS, keeping little knowledge on the thematic; it was also noticed that most of them did not know about the disease before the educative intervention. Because of that, the practice of education in health for such population must be emphasized.

The methodology employed provided a critical dialog with the subjects of the research promoting actions which contributed for the theoretical deepening. Thus, it is understood that this method proved to be effective in the realization of the goal.

As a limitation of the work is worth highlighting that our study did not take into consideration the functional illiteracy of the target public, so many participants may not have precisely understood the questions of the questionnaire and may have answered them erroneously.

According to the above mentioned, a transformation in the knowledge of the elderly concerning AIDS was observed and such change occurred due to the dialog expositive class as an instrument of education in health.

The increase of incidence of AIDS among the elderly is many times due to the lack of knowledge of the disease, and as a result of that, the importance of studying this context bearing in mind the supply of subsidies to keep them conscious of the disease is outstanding. It is obvious that there is the need of such actions is made as campaigns of education to dissipate the myths of infection by HIV make the elderly able to understand the risks.

Consequently, it is expected that this study may have contributed for the reflection and comprehen- 
sion of the health/nursing professionals on the potentialities concerning the educative practices to be incorporated as a way to prevent AIDS and commit themselves to offer quality assistance aiming at effective measures in the preventive actions and complete assistance to the health of the elderly, without any kind of discrimination.

\section{Collaborations}

Isoldi DMR contributed for the collection, organization, analysis and interpretation of the data, and writing of the article. Cabral AMF assisted in the construction of the article and provided support the revisions. Simpson CA guided and assisted in the construction of the article and the revisions.

\section{References}

1. Melo HMA, Leal MCC, Marques APO, Marino JGO. Conhecimento sobre Aids de homens idosos e adultos jovens: um estudo sobre a percepção desta doença. Ciênc Saúde Coletiva. 2012; 17(1):43-53.

2. Garcia GS, Lima LF, Silva JB, Andrade LDF, Abrão, FMS. Vulnerabilidade dos idosos frente ao HIV/ Aids: tendências da produção científica atual no Brasil. J Bras Doenças Sex Transm. 2012; 24(3):183-8.

3. Batista AFO, Marques APO, Leal MCC, Marino JG, Melo HMA. Idosos: associação entre o conhecimento da aids, atividade sexual e condições sociodemográficas. Rev Bras Geriatr Gerontol. 2011; 14(1):39-48.

4. Czeresnia D. 0 conceito de saúde e a diferença entre prevenção e promoção. In: Czeresnia D. Promoção da saúde: conceitos, reflexões, tendências. Rio de Janeiro: Fiocuz; 2009.

5. Rodrigues D, Santos VE. A Educação em Saúde na Estratégia Saúde da Família: uma revisão bibliográfica das publicações científicas no Brasil. Health Sci Inst. 2010; 28(4):321-4.

6. Falkenberg MB, Mendes TPL, Moraes EP, Souza EM. Educação em saúde e educação na saúde: conceitos e implicações para a saúde coletiva. Ciênc Saúde Coletiva. 2014; 19(3):847-52.

7. Gadelha RS, Carneiro MAM, Medeiros JDPL.
Serviço de atendimento ao idoso. Parnamirim: Câmara dos Deputados; 2014.

8. Maschio, MBM, Balbino AP, De Souza PFR, Kalinke LP. Sexualidade na terceira idade: medidas de prevenção para doenças sexualmente transmissíveis e AIDS. Rev Gaúcha Enferm. 2011; 32(3):583-9.

9. Pereira GS, Borges CI. Conhecimento sobre HIV/ aids de participantes de um grupo de idosos, em Anápolis-Goiás. Esc Anna Nery. 2010; 14(4):7205.

10. Souza MHT, Backes DS, Pereira ADA, Ferreira CLL, Medeiros HMF, Marchiori MRCT. Nível de conhecimento de um grupo de idosos em relação à Síndrome da Imunodeficiência Adquirida. Av Enferm. 2009; 27(1):22-9.

11. Toledo LSG, Maciel ELN, Rodrigues LCM, TristãoSá R, Fregona G. Características e tendência da Aids entre idosos no Estado do Espírito Santo. Rev Soc Bras Med Trop. 2010; 43(3):264-7.

12. Rumor PCF, Berns I, Heidemann ITSB, Mattos LHL, Wosny AM. A promoção da saúde nas práticas educativas da saúde da família. Cogitare Enferm. 2010; 15(4):674-80.

13. Oliva J, Galindo S, Vives N, Arrillaga A, Izquierdo A, Nicolau A, et al. Retraso diagnóstico de la infección por el virus de la inmunodeficiencia humana en España. Enferm Infecc Microbiol Clin. 2010; 28(9):583-9.

14. Lekalakala-Mokgele E. Understanding of the risk of HIV infection among the elderly in Ga-Rankuwa, South Africa. J Soc Aspec HIV/AIDS. 2014; 11(1):67-75.

15. Sales JCS, Teixeira GBSF, Sousa HO, Rebelo RC. A percepção do idoso de um centro de convivência de Teresina - PI sobre a AIDS. Rev Min Enferm. 2013; 17(3): 620-7.

16. Alexandre SG, Pereira MLD, Monte RS, Brasil EGM, Barbosa JSM, Moura SKB. Social representations of sexuality developed by women in the context of Aids. Rev Rene. 2013; 14(1):120-9.

17. JúniorJSM, Gomes R, Nascimento EF.Masculinidade hegemônica, vulnerabilidade e prevenção ao HIV/ AIDS. Ciênc Saúde Coletiva. 2012; 17(2):511-20.

18. Laroque MF, Affeldt AB, Cardoso DH, Souza GL, Santana MG, Lange C. Sexualidade do idoso: comportamento para a prevenção de DST/AIDS. Rev Gaúcha Enferm. 2011; 32(4):774-80. 